\title{
A short history of the 1948 Arnhem Land Expedition
}

\author{
Martin Thomas
}

The American-Australian Scientific Expedition to Arnhem Land is sometimes referred to as the 'last of the big expeditions'. Despite the hype (and there was plenty of that), exploration - at least in the terrestrial sense - was not its purpose. Rather, it was the frontier of knowledge that members of the Expedition hoped to penetrate. This involved co-ordinated study of both the natural environment and its Aboriginal inhabitants. Occurring in the aftermath of World War II, the Arnhem Land Expedition was a watershed event, emblematic of broader transformations in Australia and beyond. In terms of diplomatic objectives, it reflected the desire of Ben Chifley's Labor Government, then in its last days, to shore up the relationship with the United States through an overt display of collaboration between the two nations. Widely reported in the press, and transmitted to the world through film, radio and print media, this 'friendly mission' was a public face to behind-the-scenes negotiations that would shape the trans-Pacific relationship for the remainder of the twentieth century. ${ }^{1}$ Domestic support for the Arnhem Land Expedition is indicative of the pro-American sentiments of Australia's major political parties, then adjusting to a post-war climate of decolonisation and the demise of Britain as a global power. It was Chifley's successor, Robert Menzies, who signed the Australia, New Zealand, United States Security Treaty (ANZUS) in 1951.

The United States already had a long history of using cultural, scientific and educational programs to pursue its strategic and political interests in foreign nations. Before the war, philanthropic foundations had funded much of this work. ${ }^{2}$ This had a direct bearing upon Australian Aboriginal studies, for it was Rockefeller funding in the 1920s that established the Department of Anthropology at Sydney, the first in an Australian university. ${ }^{3}$ After the war, with the establishment of the Fulbright Program in 1948, the American taxpayer became directly involved in this sort of 'soft' diplomacy. That the Arnhem Land Expedition was born of similar sentiments, and that it provided a useful opportunity for keeping a paternal eye on developments in Australia, is indicated by a now declassified report to the Secretary of State in Washington, dated December 1948. Its author was the American Consul in Adelaide, Elvin Seibert, who spent a fortnight travelling the Territory while the Expedition was

1 Beazley 2011.

2 Berman 1983; Rosenberg 1982; White 1997.

3 Gray 2007: 147-148. 
in progress. His report is richly inscribed with the values of the epoch, most noticeably the Cold War anxieties that played no small part in its inception. The tone, as well as the content, of the reportage gives insight into the way Australia's vast, though sparsely populated, Northern Territory was viewed from afar as an object of strategic interest - and as the subject of considerable condescension. Seibert speculated on the 'pinkness or redness' of unionists and bureaucrats in Darwin. He showed intense curiosity about Britain's doings in this part of the country: Lord Vestey's role in the cattle industry and especially the new rocket base at Woomera. He commented on the excellent condition of the wartime airstrips, though the Territory's 'leading personalities' he found less agreeable. 'The interests and activities of practically all are extremely local. Most of the civil servants are small-bores', he complained. On the Territory's race relations, Seibert observed that:

\begin{abstract}
opinion was very much in favour of the 'White Australia Policy', and people seemed to be very conscious of the 'teeming millions of Asia' casting their eyes covetously on the undeveloped vacancy of northern Australia ... The Territory ... admits that its mineral possibilities will never be developed properly with white labor, and wishes the Aborigines were not so highly protected that it is practically impossible to employ them below ground, but it still - in my observation - is thoroughly satisfied with the White Australia Policy. ${ }^{4}$
\end{abstract}

Seibert's observations on the Arnhem Land Expedition, which he visited briefly, when it was based at the mission settlement of Yirrkala, I will get to later. Even this brief summary is sufficient to establish that early in the Cold War the bilateral relationship was complicated by an ensemble of strategic and propagandist agendas that inevitably affected a prominent joint undertaking such as a scientific expedition. At times, the imperative to project an image of transnational harmony put strain on the Expedition's researchers, and it is possible that the uneasy melange of research and politics damaged the credibility of their work in scientific, and especially anthropological, circles. As we will see, key players in Australian anthropology were sidelined by this high-profile venture, and it came to be derided it as a populist extravagance. Yet the fact that the event exposes certain fault-lines in the politics of academia does not diminish - and arguably heightens - its significance to the history of science, anthropology and the visual arts. This was due to the unique accomplishments of its participants, and also to the Aboriginal people who shared their knowledge and provided practical support. Yet it was also due to the Expedition's timing. It occurred at a moment when the very purpose of scientific and environmental research was being reconsidered. ${ }^{5}$ This was a moment when old disciplinary boundaries were up for reconsideration and ecological thinking was on the ascendant. The interdisciplinary makeup of the Expedition was intended to encourage cross-

4 Seibert to Secretary of State, 24 December 1948, Records of Foreign Service Posts of the Department of State, Australia, Canberra Embassy, Confidential File 1948 RG 84, Box 16, National Archives and Records Administration [hereafter NARA], College Park, Maryland.

5 MacLeod 2000: 5. 
pollination among the researchers, who returned from the Northern Territory with an array of data and new methodologies, and huge quantities of natural history specimens and Aboriginal artefacts, now held by major institutions in Australia and the United States.

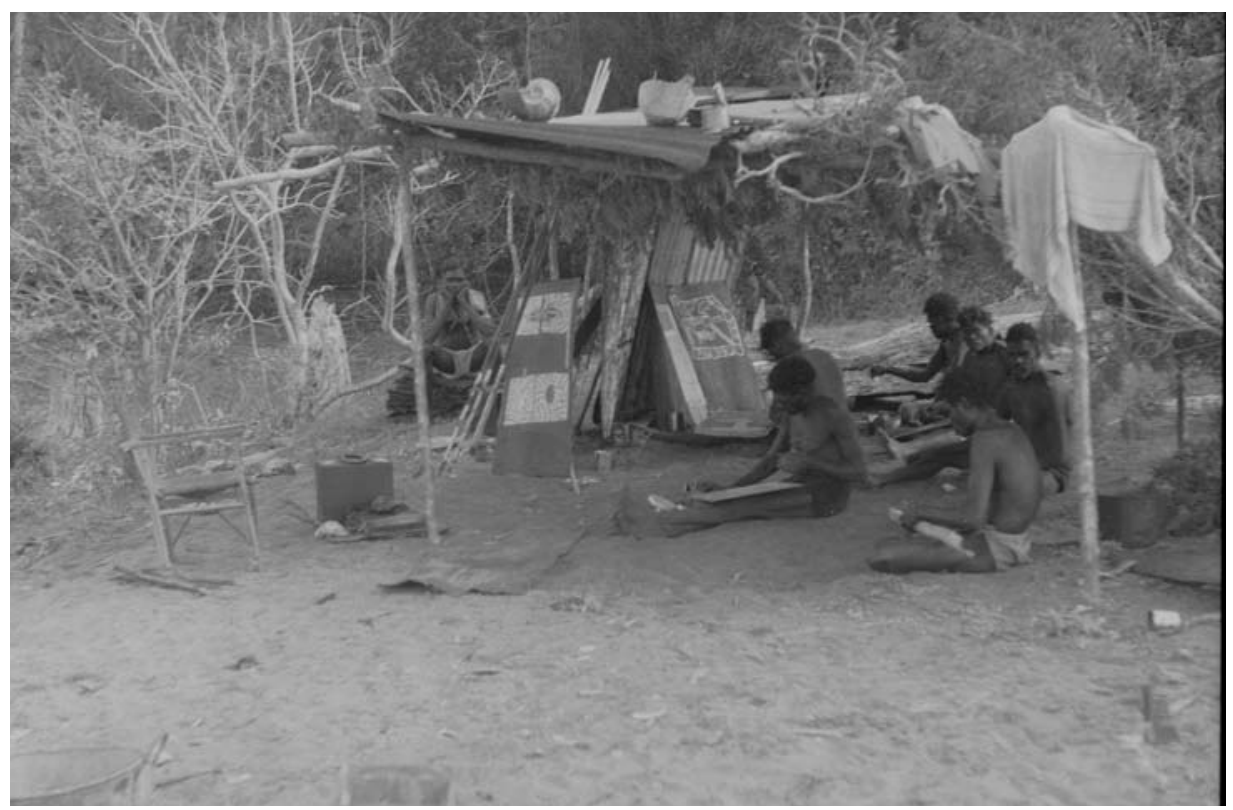

Fig 1. Painters and wood carvers at work at Yirrkala making objects collected by the Arnhem Land Expedition, 1948.

Source: Photograph by Frank Setzler. Photo Lot 36, Drawer 8. By permission of the National Anthropological Archives, Smithsonian Institution.

\section{Beginnings}

The Arnhem Land Expedition was led by Charles P Mountford (1890-1976), the Adelaide-based photographer and ethnologist. Although his star has waned in recent decades, 'Monty', as friend and foe alike knew him, was a well-known and at times controversial figure. At a time when Aboriginal people had little voice in public culture, he became a leading spokesman on matters Aboriginal. The press frequently sought his opinions, and he was adept at publicising himself and his activities. Mountford's emergence as a scholar, photographer and filmmaker is a remarkable story. He had no academic qualifications in anthropology or anything else - a deficiency that irked some powerful gatekeepers, particularly the University of Sydney anthropologist Professor AP Elkin who immediately queried his credentials when the Expedition was announced in the Australian press. ${ }^{6}$

6 Elkin to Secretary of the National Geographic Society, 30 May 1945 (copy), Correspondence 194549, vol 1 1945-47, PRG 1218/17/4, American/Australian Scientific Expedition to Arnhem Land 1948 Records, State Library of South Australia [hereafter SLSA], Adelaide. 
Mountford's unsavoury encounters with academia were numerous. An oral history interview, recorded by Hazel de Berg in 1966, suggests they led to some residual bitterness. ${ }^{7}$ In part, the prejudice against Mountford reflected the class distinctions then very much alive in Australian society, for Mountford was 'in trade' rather than a profession. Born into impoverished circumstances in rural South Australia, he had only minimal schooling. By the age of ten, he was working with his father as a camera salesman. Later, the family moved to Adelaide where he became a tram conductor. Eventually, he attended evening courses and became qualified as a telephone mechanic. For many years, he worked in this capacity for the Department of the Postmaster General. Highly talented as a photographer, Mountford was encouraged by the Anthropological Society of South Australia and the South Australian Museum to document Aboriginal art sites around Adelaide. Norman B Tindale and Frederic Wood Jones were two figures, influential in Aboriginal studies, who gave him early support. ${ }^{8}$ Australian anthropology owed its origins to a circle of self-trained devotees that included AW Howitt, Lorimer Fison, RH Mathews, John Mathew and WE Roth. Mountford was a latter-day exemplar of this amateur tradition, though later in life he did receive academic recognition.

Mountford's ethnological interests began to coalesce in the latter part of the 1920s when he participated in small-scale anthropological expeditions, organised from Adelaide. In the 1930s, he travelled through remote parts of South Australia, Western Australia and the Northern Territory. He made early sound recordings of Aboriginal singers and developed an interest in traditional art forms. He took paper and crayons to several remote communities and encouraged knowledge-holders to express stories or dreamings in visual form. He became acquainted with the renowned watercolourist from Hermannsburg, Albert Namatjira, whom he depicted in a book and a documentary film (for which he was credited as associate producer)..$^{9}$ In 1940, he travelled for four months around Ayers Rock (Uluru) and the Olgas (Kata Tjuta), studying art and mythology. This resulted in the book Brown Men and Red Sand (1948) and a film of the same title.

Mountford's extraordinary footage of the Centre, shot with Aboriginal family groups who were still living a predominantly nomadic lifestyle, had a direct bearing on the Arnhem Land Expedition. Towards the end of World War II, after a screening of his work in Canberra, Mountford came to the attention of Arthur Calwell, who was Minister for Information for much of the war. Calwell, who is best remembered as Chifley's Minister for Immigration and as leader of the Australian Labor Party in the 1960s, was of Irish-Australian background. Sceptical of Australia's historical attachment to the United Kingdom, he regarded the United States as the

7 Mountford in interview with Hazel de Berg, 28 October 1966, Hazel de Berg Collection, National Library of Australia Oral History Collection [hereafter NLAOHC], Oral DeB 189.

8 Lamshed 1972; Jones 2000.

9 Mountford 1944; Robinson 1947. 
more progressive and egalitarian model of democracy. Ever eager to bolster his government's profile with its wartime ally, he sent Mountford to the United States in 1945-46. His mission was to spread the good word about Australia in a series of film screenings and public lectures. It was neither the first nor the last occasion when white Australia would use images from Aboriginal culture to promote its political and national interests abroad.

Mountford gave presentations throughout the United States, but arguably the most significant occurred before the National Geographic Society in Washington DC where the audience numbered 4000. Among them was Dr Gilbert H Grosvenor, the society's president, who is sometimes described as the 'father of photojournalism'. For 55 years, he edited National Geographic, transforming it from an obscure, learned journal to the yellow-rimmed icon known throughout the world. ${ }^{10}$ Grosvenor invited Mountford to dinner at the Cosmos Club, the exclusive haunt of Washington's scientific and cultural cognoscenti where the National Geographic Society had started in 1888. Grosvenor commissioned an article about Mountford's experiences around Uluru and Kata Tjuta, published under the lurid title, 'Earth's Most Primitive People: A Journey with the Aborigines of Central Australia' ${ }^{11}$ In his interview with de Berg, Mountford vividly recalled the evening with Grosvenor. When the latter mentioned that the National Geographic Society had a research fund, and asked if he had an idea worthy of support, Mountford responded: 'I've got more ideas than a dog's got fleas'. ${ }^{12}$ As discussions proceeded, it was the concept of an expedition to Arnhem Land that they settled upon, and with Grosvenor's imprimatur, an initial grant of US\$8500 was rapidly approved by the Society. ${ }^{13}$ The Arnhem Land Expedition was born.

\section{The Expedition takes shape}

Mountford had worked in Darwin before the war, but had never set foot in Arnhem Land. Through collections in the South Australian Museum, he became aware of the region's richness in terms of art and other material culture - as we know from a paper on Arnhem Land paintings, collected by Norman Tindale and others, that Mountford published in $1939 .{ }^{14}$ Extending from the Gulf of Carpentaria, and bordered on its western flank by what is now Kakadu National Park, Arnhem Land is a vast terrain of 97,000 square

10 Vosburgh 1966.

11 Mountford 1946.

12 Charles P Mountford in interview with Hazel de Berg, 28 October 1966, NLAOHC, Oral DeB 189.

$13 \$ 8500$ was the initial amount sought in Mountford's grant application and paid to the University of Adelaide which agreed to manage the funds on his behalf. The National Geographic Society allocated a further $\$ 1500$ to meet in-house costs 'such as photographic equipment and supplies ... and contingencies'. Thomas McKnew to Alexander Wetmore, 3 September 1947, Arnhem Land Expedition file 178294, Accession Files RU 305, Smithsonian Institution Archives [hereafter SIA], Washington DC.

14 Mountford 1939: 365-371. 
kilometres, classified as an Aboriginal reserve since 1931. In his application to the National Geographic Society, Mountford made much of the lack of contact between Arnhem Landers and the outside world.

Arnhem Land is an aboriginal reserve, and before the war, except for a few missions along the coast, was uninhabited by Europeans. The native culture was not at that time influenced by white civilisation; it is unlikely that the present military occupation has changed them, for the natives are not allowed near the camps. ${ }^{15}$

This claim, as Mountford would discover, was completely erroneous. As the first line of defence against Japanese invasion, the northern coast had been flooded with military personnel. They did interact with Arnhem Landers, many of whom participated in the war effort. This is to say that the Pacific War, which had made the Expedition politically expedient, also had enormous impact upon the Aboriginal communities where the scientists worked and studied.

Mountford's bid for funding proposed research into four aspects of Aboriginal life: the 'Art of Bark Paintings'; the 'Art of Body Paintings'; the 'General Ethnology' of the people; and 'Music in Secular and Ceremonial life'. Scientific papers, photography, films and articles for National Geographic were among the intended outcomes. Mountford wrote his application in the first person and gave little indication of how many - if any - fellow travellers would partake in the adventure. He gave only faint hint that it might be more than a solo undertaking: 'I would welcome the collaboration of other scientists, especially those interested in the life of the fauna and flora of the swamps or the coral reefs.' This was the sole indication at this early stage that the expedition might segue from ethnological research to branches of the natural sciences.

\section{A trio of sponsors}

While the funding granted by the National Geographic Society was substantial for the period, it is probable that the Arnhem Land Expedition would have remained an essentially modest affair, involving Mountford and perhaps a few others, had it not caught the attention of another flagship organisation in Washington, the Smithsonian Institution (a huge complex of museums and research facilities). In the 1940s, under the leadership of Secretary Alexander Wetmore, the Smithsonian enjoyed an exceptionally close relationship with the National Geographic Society. Wetmore, a renowned ornithologist and field collector, was friendly with Grosvenor and served on National Geographic committees. Dogged by a limited travel budget for his staff, he was consistently amenable to suggestions

15 Application to Chairman of the Research Committee, National Geographic Society, 5 March 1945, Correspondence 1945-49, vol 1 1945-47, PRG 1218/17/4, American/ Australian Scientific Expedition to Arnhem Land 1948 Records, SLSA. 
for partnerships and joint ventures. Correspondence in the Smithsonian Archives suggests that it was Mountford who began to canvass the idea of recruiting some American scientists. Grosvenor supported him and brokered the contact with Wetmore. ${ }^{16}$ This resulted in Mountford visiting the Smithsonian to spruik his plans. Wetmore immediately discerned a strategic opportunity to correct the Institution's under-representation in its Australian holdings. The Smithsonian's decision to sign up as an official partner was undoubtedly influenced by the preparedness of the National Geographic Society to allocate a further $\$ 10,000$ 'to cover transportation, subsistance [sic] and incidental expenses' incurred by the four scientists who would go to Arnhem Land. They were away from home for almost all of 1948.

From the outset, Grosvenor was attentive to the significance of the event in terms of international relations. Early in the planning process, he wrote to Sir Frederic Eggleston, then serving as Australian Minister to the United States, expressing his ultimate vision for the project.

I trust that your Government will be able to assist in this scheme, thus making it a joint Australian-United States research expedition. Such help will increase still further the links that already bind your Nation to ours, as well as add greatly to the scientific knowledge of this little-known part of your Continent. ${ }^{17}$

Mountford was enthralled at the way his film and Aboriginal art project was snowballing. The joint involvement of two American icons, the National Geographic Society and the Smithsonian Institution, ultimately proved too significant for Australian politicians to ignore. The government view, articulated by Eggleston, was that 'a joint United States-Australian research expedition, such as this, will increase still further the links binding our respective countries' ${ }^{18}$ Sensing a valuable diplomatic opportunity, Calwell arranged for the Commonwealth of Australia to sign up as the third official partner. He liaised with other branches of Government and won support, particularly from the armed services who agreed to fly the researchers between the major bases. Australia's expenditure on staff, travel and equipment would rapidly eclipse the American commitment.

Two years after the Expedition was first announced, Mountford prepared a document for Grosvenor, stating the objectives as they now appeared.

16 Grosvenor wrote: 'In a conference with Mr. Mountford several days ago, he suggested adding several American scientists to the staff. We agreed, subject to your approval, that it is desirable that the additional scientists be selected by the Smithsonian Institution.' Grosvenor to Wetmore, 25 October 1945, Arnhem Land Expedition file 178294, Accession Files RU 305, SIA.

17 Grosvenor to Eggleston (copy), 31 May 1945, Arnhem Land Expedition file 178294, Accession Files RU 305, SIA.

18 Eggleston to Grosvenor (copy), 11 June 1946, Correspondence 1945-9, vol 1 1945-47, PRG 1218/17/4, American/Australian Scientific Expedition to Arnhem Land 1948 Records, SLSA. 
The original four point plan, dedicated to the study of Arnhem Land art, myth and music, had broadened into a nine point agenda, topped by some grandiose ambitions that were anything but specific to Arnhem Land.

(a) To establish a good neighbour policy and scientific cooperation between the United States of America and Australia.

(b) To provide publicity for Australia through the publication of three, if not four, illustrated articles in the National Geographic Magazine. (Circulation 1,250,000. Estimated Readers 5,000,000.)

(c) To study and record the aborigine's pattern of life in relation to the terrestrial and marine fauna and flora.

(d) To investigate seasonal movements and shelter of the aborigines, and, by examination of their foods determine how well, or otherwise, they are able 'to live off the land'.

(e) To make a nutritional health survey of the natives and their food as a guide for future administration.

(f) To collect and identify the plants, birds, animals and fish in the various environments of Arnhem Land.

(g) To carry out a fish survey along the coast of Arnhem Land.

(h) To determine the food resources of land and sea as data for future military operations. (This was urgently needed, but not available, during the last war.)

(i) To produce, for the National Film Board, five coloured cine films on the ethnology and natural history of Arnhem Land. ${ }^{19}$

These freshly minted objectives reflect the array of interests and institutions that had become involved in the two years since approval of National Geographic funding, and they provide a fairly realistic outline of what it set out to accomplish. In terms of the locations to be visited, Mountford now envisaged a multi-stop tour with Royal Australian Air Force planes transporting the researchers between five main bases: Groote Eylandt ('An island environment with a distinctive ethnological culture'); the Anglican mission on Roper River (a 'fresh water swamp land environment'); Melville Bay ('air strip with ample accommodation and an outpost of the Department of Native Affairs'); Crocodile Island (Millingimbi) ('Many aborigines practising a forest culture'); and Oenpelli (now Gunbalanya) ('ethnology centres around unusual motifs in their art and elaborate ceremonies'). ${ }^{20}$

19 Mountford to Grosvenor (copy), 28 January 1947, Arnhem Land Expedition file 178294, Accession Files RU 305, SIA.

20 Mountford to Grosvenor (copy), 28 January 1947, Arnhem Land Expedition file 178294, Accession Files RU 305, SIA. 
As it transpired, this plan was too ambitious. The visit to Roper River was abandoned and instead of Melville Bay, the expeditioners established themselves at the Methodist mission of Yirrkala on the Gove Peninsula. Millingimbi was never an Expedition base, although two researchers (Frederick McCarthy and Frank Setzler) made a side trip there while the rest of the party were at Yirrkala.

\section{The participants}

The Expedition was initially intended for 1947, but delays at both ends necessitated postponement. In terms of administrative complexity, the scale of the enterprise was well outside Mountford's experience. One of the difficulties arising from having a triad of sponsors was a lack of say in the choice of personnel. From the moment the Expedition was announced in the press, Mountford was bombarded with applications from would-be expeditioners, offering services as cooks and anthropologists, doctors and errand runners - and much else in between. These letters reveal the rapidity with which the Arnhem Land Expedition captured the public imagination. ${ }^{21}$

Only two of these applicants won a spot on the Expedition. One was the cook and quartermaster John Bray who also served as honorary entomologist. The other was WE or Bill Harney, the Northern Territory patrol officer and bushman writer, who joined them in Yirrkala as official guide. Mountford already knew him, as did many other anthropologists who sought his local knowledge and contacts when brokering relationships with Aboriginal communities in the north. However, most of the Expedition participants, selected by the institutions that became stakeholders in the venture, were unknown to Mountford until they assembled in early 1948 and began the parade of receptions and send-offs that preceded their flight north to Darwin from Adelaide. In Australia, the main participating institutions were the Australian Museum in Sydney and the Institute of Anatomy in Canberra. On both sides of the Pacific, there had been argument about who should go, and it was only towards the end of 1947 that the final composition of the team was more or less established. With some turnover in support staff occurring during the Expedition, its official membership eventually numbered 17, listed as follows in the official Records: ${ }^{22}$

21 Correspondence 1945-48, vol 2, PRG 1218/17/5, American/Australian Scientific Expedition to Arnhem Land 1948 Records, SLSA.

22 Mountford 1956: xi. 


\section{List of staff on 1948 Expedition}

\begin{tabular}{|c|c|c|}
\hline Name & Role & Institutional Affiliation \\
\hline $\begin{array}{l}\text { Charles P } \\
\text { Mountford }\end{array}$ & $\begin{array}{l}\text { Leader, Ethnologist and } \\
\text { Film Director }\end{array}$ & $\begin{array}{l}\text { Honorary Associate Curator in Ethnology, } \\
\text { South Australian Museum, Adelaide }\end{array}$ \\
\hline Frank M Setzler & $\begin{array}{c}\text { Deputy Leader and } \\
\text { Archaeologist }\end{array}$ & $\begin{array}{l}\text { Head Curator, Department of Anthropology, } \\
\text { Smithsonian Institution, Washington }\end{array}$ \\
\hline Herbert G Deignan & Ornithologist & $\begin{array}{l}\text { Associate Curator of Birds, Smithsonian } \\
\text { Institution, Washington }\end{array}$ \\
\hline David H Johnson & Mammalogist & $\begin{array}{l}\text { Curator of Mammals, Smithsonian } \\
\text { Institution, Washington }\end{array}$ \\
\hline Robert R Miller & Ichthyologist & $\begin{array}{l}\text { Associate Curator of Fishes, Smithsonian } \\
\text { Institution, Washington }\end{array}$ \\
\hline Raymond L Specht & Botanist & $\begin{array}{l}\text { Lecturer, Department of Botany, University } \\
\text { of Adelaide. (Specht held this position } \\
\text { in } 1956 \text { when the first volume of the } \\
\text { Records was published. At the time of } \\
\text { the Expedition he had recently graduated } \\
\text { from the University of Adelaide.) }\end{array}$ \\
\hline $\begin{array}{l}\text { Frederick D } \\
\text { McCarthy }\end{array}$ & Anthropologist & $\begin{array}{l}\text { Department of Anthropology, Australian } \\
\text { Museum, Sydney }\end{array}$ \\
\hline $\begin{array}{l}\text { Harrison Howell } \\
\text { Walker }\end{array}$ & $\begin{array}{l}\text { Photographer and Staff } \\
\text { Writer }\end{array}$ & National Geographic Society, Washington \\
\hline Bessie I Mountford & Honorary Secretary & NA \\
\hline William E Harney & Guide and Liaison Officer & NA \\
\hline Peter Bassett-Smith & Cine-Photographer & NA \\
\hline Keith Cordon & Transport Officer & NA \\
\hline John E Bray & $\begin{array}{l}\text { Cook and Honorary } \\
\text { Entomologist }\end{array}$ & NA \\
\hline Reginald Hollow & Cook & NA \\
\hline Brian Billington & Medical Officer & Institute of Anatomy, Canberra \\
\hline Margaret McArthur & Nutritionist & Institute of Anatomy, Canberra \\
\hline Kelvin Hodges & Biochemist & Institute of Anatomy, Canberra \\
\hline
\end{tabular}

Source: Mountford 1956: xi.

The list reveals a great deal about the Expedition and its milieu. To give the breakdown of nationalities, the team consisted of 12 Australians and five Americans. In terms of the fields of knowledge represented, the mix of professional scientists and writer-photographers set the tone for the range of outcomes - academic and popular - that was a distinctive trait of the Expedition. The gender imbalance is significant. The attendance of Mrs Bessie Mountford seems to been have a case of leader's privilege. Wetmore had opposed the idea, telling Mountford 'that ordinarily we did not favor taking women on trips of this kind.' ${ }^{23}$ The objection was overcome or ignored in Bessie's case, but none of the

23 Conversation with Mr. Mountford Regarding the Australian Expedition of 1947 (file note), 14 May 1946, Arnhem Land Expedition file 178294, Accession Files RU 305, SIA. 
others was permitted to take a spouse. (Most of the younger researchers were, in any case, unmarried.) Still, Bessie Mountford made valuable contributions to the Expedition, but because they fell into areas traditionally deemed women's labour, they were under-recognised. Mrs Monty, as they called her, was a former public servant and a skilled typist and bookkeeper. The meticulous Expedition archives, recording everything from emergencies to birthday greetings, were largely her doing.

Margaret McArthur, the other woman on the team, was anything but conventional. As Wetmore's objection indicates, there were strong prejudices in the scientific establishment against the mixing of women and fieldwork. They were overcome in her case because anthropologists had come to realise that the sex of the investigator greatly affected the work they could do in the highly gendered society of Aboriginal Australia. McArthur was trained as a nutritionist, and had only recently returned from New Guinea where she had studied the diet and health of indigenous communities. Her mission in Arnhem Land was to carry out a pioneering investigation of the diet and food-gathering techniques of clans still living a traditional lifestyle. Since food gathering (as opposed to hunting) is predominantly female work, the bulk of her research was done with women and the young children in their care. So gender was at issue in the crosscultural interactions, as it was in the Expedition's internal dynamics, a point that is illustrated by McCarthy in some candid journal entries that appraise the personalities of his companions.

Setzler is straight-forward, all on the surface, but he is not firm enough with Monty. He is jolly \& good company ... His philosophy of life is fishing, food \& sex (apart from his work) \& his remarks about the latter to Margaret are too obvious to the whole company...

Miss Macarthur [sic] is an easy going type, who admits to being lazy and enjoys it, likes to swear a bit and generally exhibits a hard exterior typical of women careerists, but is really just the opposite. She is frank and has a keen mind ready to put Setzler in his place at any moment. ${ }^{24}$

Clearly, the Expedition made for complex politics in terms of gender, as the archaeologist Anne Clarke has also argued in an analysis of McCarthy, McArthur and Setzler's scientific papers. ${ }^{25}$

The official list of personnel only hints at the range of people involved in the Expedition during its seven months in Arnhem Land, commencing in early April 1948. Some of the individuals who supported or visited them along the way are now regarded as iconic figures in Australian history. At Umbakumba on Groote Eylandt, their first base, they stayed in the Aboriginal settlement that had grown around the former Qantas depot, established before the war to refuel the Catalinas that flew the first regular service between Sydney and

24 McCarthy, 18 April 1948, Diary 1: Field Notes Groote Eylandt 1, Papers of Frederick David McCarthy, MS 3513/14/1, Australian Institute of Aboriginal and Torres Strait Islander Studies.

25 Clarke 1998. 
London. The settlement was presided over by Fred Gray, a former trepanger and all round adventurer who is rated as one of the legendary figures of the Northern Territory. ${ }^{26}$ In Yirrkala, their second base, the researchers were visited by the cartoonist Eric Jolliffe whose hilarious drawings of the scientists at work, published in Pix magazine, evoked the strangeness of their research and collecting, as it might have seemed to their Aboriginal hosts.

At Oenpelli, the third and final base, the Sydney journalist Colin Simpson joined forces with the Expedition. Formerly a newspaperman, Simpson was now working for the Australian Broadcasting Commission (now Corporation) (ABC) where he excitedly plunged into the emerging field of radio documentary. He was accompanied by technician Raymond Giles, the operator of a newfangled magnetic wire recorder (predecessor of the tape recorder). That the Arnhem Land Expedition stood proudly at the technological forefront is fully evident in its embrace of sound recording. The Expedition travelled with its own wire recorder, which Mountford put to use on Groote Eylandt where he recorded sacred song cycles. The Expedition's documentation of Aboriginal music and of several major ceremonies is now recognised as being of enormous historical significance.

\section{Activities, methods and controversy}

The wire recorder, powered by large wet cell batteries, allowed the production of fairly high fidelity recordings of extended duration. The machine's portability distinguished it from pre-war technology where location recording required a heavy truckload of equipment. The 1948 field recordings were a portent of the day when the tape recorder would become a basic tool of trade for the anthropologist. ${ }^{27}$ Simpson's assignment at Oenpelli was to make a radio production about the Expedition, recorded in situ. This he did, and the program, broadcast in late 1948, consisted of Simpson's crisp, first-person narrative, set against a backdrop of magnificent nature recordings, song performances and interviews with Mountford and other scientists. Considered a classic radio feature, the production survives in ABC Archives. Simpson went beyond mere reportage during his time in Arnhem Land. While the anthropologists filmed and photographed, he made an extended sound recording of the Wubarr ceremony, a male initiation rite, traditional to the Bininj (as the clans of West Arnhem Land are collectively known). Cultural sensitivities prevented the broadcast of this recording, although it survives in the archive. For the senior men of West Arnhem Land it provides an invaluable record of a venerated ceremony that has now fallen into abeyance.

Simpson wrote about his Arnhem Land experience in Adam in Ochre (1951), the bestseller that marked his transformation from journalist to globetrotting writer of travel books. To the contemporary reader, Adam in Ochre might seem a suspect

26 Cole 1984.

27 Thomas 2007a. 
title, but its influence in transforming attitudes to Aboriginal Australians was profound. Simpson was intrigued by Margaret McArthur's realisation that far from being impoverished, the hunter-gatherer diet was nutritionally sound. The impoverishment, he argued, existed on the missions and cattle stations that exploited Aboriginal labour. This he regarded as a national disgrace and as a breach of Australia's human rights obligations. Informed by the internationalism of the post-war moment, Simpson cited UNESCO data that put paid to the assumption that there were biological differences, or variations in intelligence levels, between the races of humanity. ${ }^{28} \mathrm{He}$ castigated the indifference of white Australia to its black population, and cited recent population data to debunk the 'dying race theory'. He argued, correctly, that the Aboriginal population was actually increasing. ${ }^{29}$

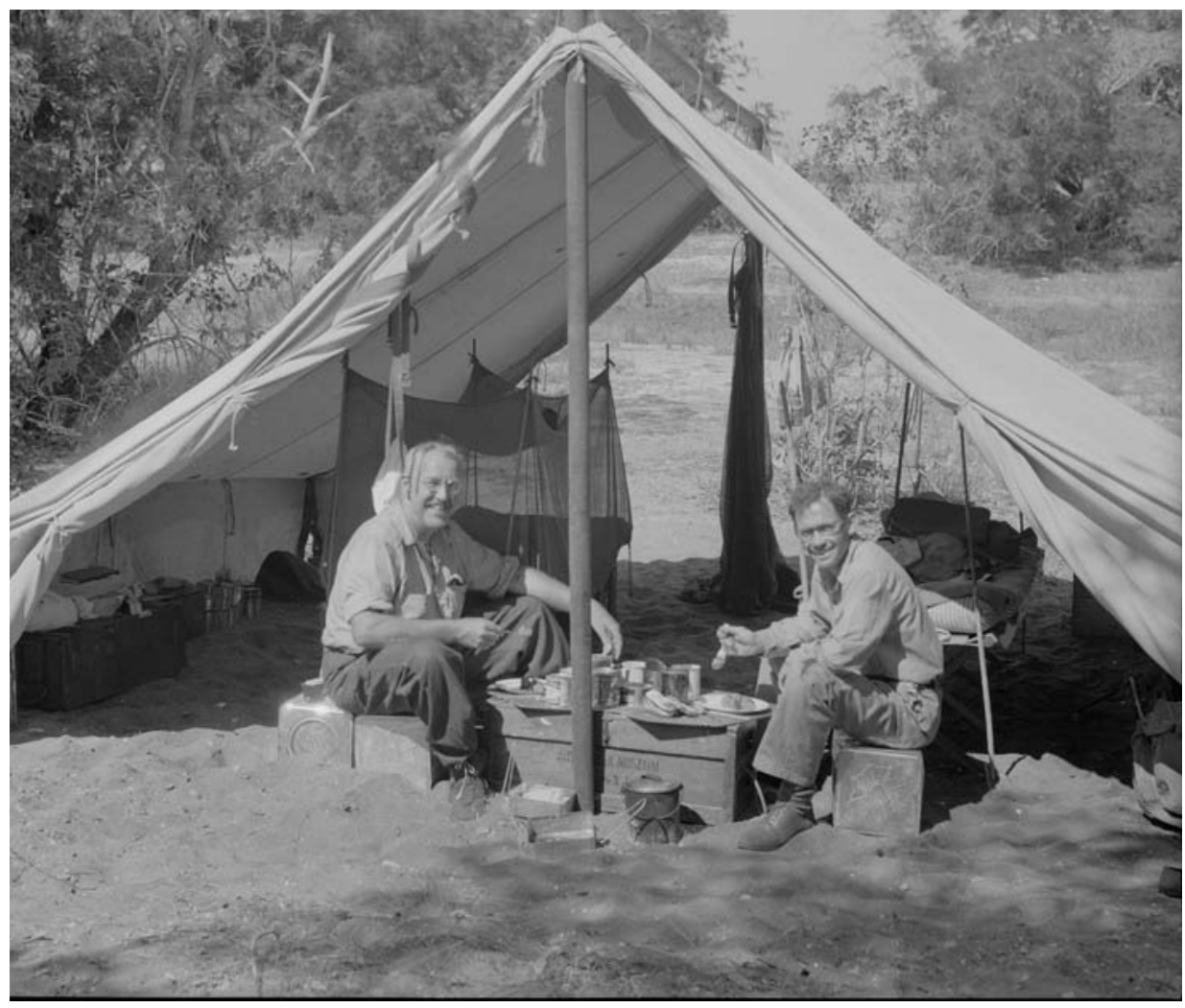

Fig 2. Deputy Leader of the Expedition, Frank M Setzler (left), and Australian Museum anthropologist Frederick D McCarthy camped on Winchelsea Island in 1948.

Source: Photograph by Frank Setzler. Photo Lot 36, Drawer 7. By permission of the Smithsonian Institution, National Anthropological Archives.

28 Simpson 1951: 193-194.

29 Simpson 1951: 186. 
Simpson's book is rewarding reading, vivid in its portraiture of the Expedition's personalities and how they spent their days building up collections and data. For a sense of its research output, the four-volume Records of the AmericanAustralian Scientific Expedition to Arnhem Land (1956-64) provide, in their 2000 pages, a panoramic overview of the range of work completed. Volume 1 is Art, Myth and Symbolism, written solely by Mountford. It and the succeeding volumes detail a herculean labour in terms of collection. The bounty included 13,500 plant specimens, 30,000 fish, 850 birds, 460 other animal specimens, and several thousand Aboriginal artefacts and paintings. To these can be added the films, sound recordings and thousands of photographs. Paperwork generated by the Expedition, including field journals and letters home to colleagues and loved ones, provides a multitude of perspectives on the researchers' interactions with Aboriginal people and each other. Most of the fauna collections are held by the Smithsonian Institution's National Museum of Natural History. Sets of plant specimens, laboriously preserved by Raymond Specht, were lodged with leading herbaria within Australia and overseas.

The journals of Mountford, Setzler and McCarthy reveal that something of a 'turf war' developed among the anthropologists. The interpersonal tensions, almost inevitable during fieldwork of such duration, were worsened in the early, formative days by the stranding on a reef near Millingimbi of the Phoenix, a dilapidated barge that was hired to transport most of the equipment. This limited the scientific work that could be done during the first phase of the Expedition, and was the prime reason for abandoning the planned base at Roper River. Rumblings of discontent reached Canberra, to the extent that Kevin Murphy, Calwell's Director of Information, saw fit to fly to Yirrkala and pay the Expedition a surprise visit. With him were AR Driver, the Administrator of the Northern Territory, and American Consul Seibert, then in the middle of his northern tour. The purpose of the visit was to sack Mountford from the leadership and install Setzler in his place. After deliberation among the Americans, however, Setzler declined the promotion. According to Mountford's biographer, Max Lamshed, the Smithsonian naturalists, at the urging of Herbert Deignan, decided that a local must lead an expedition on Australian soil. So Mountford remained in the executive role. ${ }^{30}$

The attempted deposing of Mountford is too complex a story, told from too many points of view in the primary sources, to deal with here in its entirety. Unsurprisingly, Mountford was humiliated by the incident and it cast a long shadow over the remainder of his time in Arnhem Land. Seibert's report on the incident is worthy of brief consideration, for it shows how the Expedition was being scrutinised from afar, and it clears up the question, raised by his presence, of whether there was backing in Washington for the demotion. On the latter point, Seibert is very clear. Until briefed by the Australians, he was unaware that relations on the Expedition were 'not happy'. He intentionally remained out of earshot while Mountford and Setzler were in conference with the two

30 Lamshed 1972: 138-139. 
bureaucrats. He was there as an onlooker only, though it is possible that Driver and Murphy used his presence to strengthen their case. Seibert's perception of the situation was based on Australian intelligence and brief discussions with the American scientists. Thus informed, he relayed a blunt assessment to his masters in Washington.

I gathered that Mr. Mountford, who apparently is at best an amateur anthropologist but an excellent photographer, was supposed by the Department of Information to be devoting himself principally to photography but was actually working chiefly on anthropology. It appears that he had had no experience in planning, organizing and leading an expedition of such size; had neither any conception of the preparatory work to be done in the 6 months he was given for the purpose nor anything like sufficient local knowledge; and was unaware of his own limitations ... It appears that his leadership was weak, vaccilating [sic], arbitrary, and characterized by bad judgement, and that he would take advantage of his position to enlist, at each camp, an unfair proportion of the available natives in his particular phase of activity, to the detriment of the scientific work of the other members of the party ... It appears that for about a fortnight after our visit Mr. Mountford's leadership was better, but that he then relapsed into his former ways. ${ }^{31}$

The worst relations were between Mountford and McCarthy. The latter, in Mountford's mind, bore the taint of Elkin, since he had studied under him at the University of Sydney and worked for the Australian Museum where Elkin was a trustee. Mountford suspected that McCarthy was responsible for leaking unfavourable reports on his leadership to the Canberra bureaucracy, but there is no evidence for this. Disaffection with Mountford was shared by many on the Expedition. Murphy's intelligence came from FW Clements, Director of the Institute of Anatomy, who had received a relentless flow of unflattering reports on Mountford from Brian Billington, the Expedition doctor. ${ }^{32}$ To some degree, the crossovers in their work can explain the disagreement between McCarthy and Mountford. Unlike the naturalists, who represented discrete disciplines, there was much more likelihood of the anthropologists treading on each other's toes. Setzler and McCarthy managed to navigate these difficulties, entering into a sometimes uneasy alliance. Although Setzler did not share McCarthy's interest in direct ethnographic research (resulting in his important documentation of string figures at Yirrkala), they willingly worked together on archaeological digs. They enjoyed a fruitful collaboration on their side trip to Millingimbi, divorced from the stresses of Mountford and the larger party. McCarthy and Setzler maintained a long correspondence after the Expedition that reveals on both sides a great deal of rancour towards Mountford. ${ }^{33}$ The editing of the official Records, the fate

31 Seibert to Secretary of State, 24 December 1948. Records of Foreign Service Posts of the Department of State, Australia, Canberra Embassy, Confidential File 1948 RG 84, Box 16, NARA.

32 Correspondence in file titled 'Survey Arnhem Land 1947-8', Institute of Anatomy Records, Series No A2644/1, Item 50/11 Section 1, National Archives of Australia, Canberra.

33 General Correspondence 1949 A-Q and General Correspondence 1950, Frank Maryl Setzler Papers 1927-1960, Boxes 7 and 8, National Anthropological Archives, Smithsonian Institution, Suitland, Maryland. 
of the ethnological collections, and the films arising from the Expedition were all subjects of disagreement. Mountford was particularly protective of his art study which involved the commission of hundreds of paintings on bark and paper from artists at all the main locations visited. As the archaeologist Sally K May has shown in her study of the paintings and other artefacts, the carve-up of the ethnological collections among sponsoring institutions was deeply political, and marked a further breakdown in the 'friendly mission' sentiments, espoused in the Expedition publicity. ${ }^{34}$ The Australian Museum and the Smithsonian acquired the lion's share of paintings and also an extraordinary array of Arnhem Land artefacts, including baskets, fish nets, weapons and ceremonial objects. The National Museum of Australia also has significant holdings, as do Australia's six state art galleries.

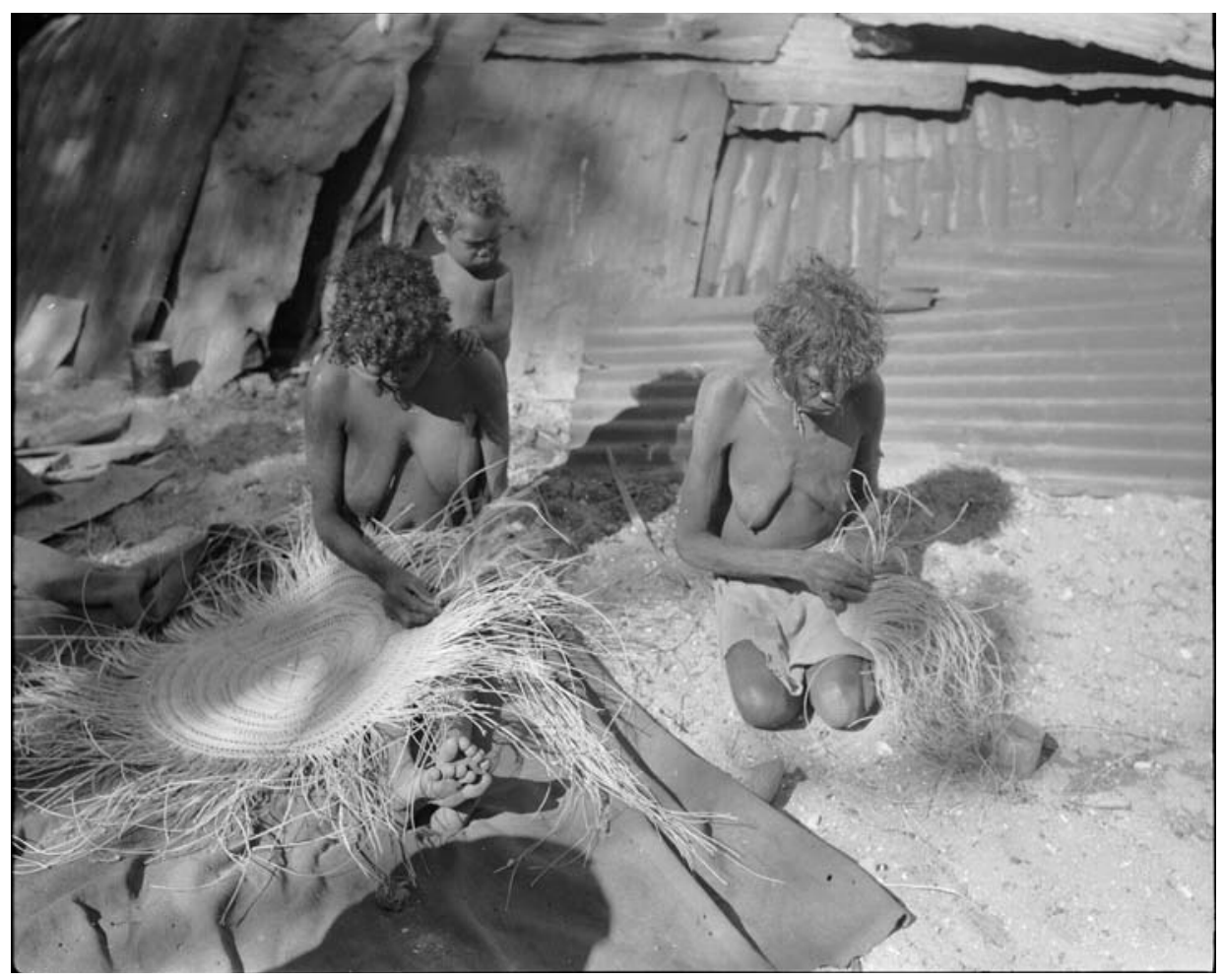

Fig 3. Mininyala Wubulkarra of the Mandjikay clan (left) and Ngulurru of the Djambarrpuyngu clan making twined objects outside a humpy on Millingimbi Island in 1948. The child is Djakala Garrawurra. Identification by Joe Neparrnga Gumbula in interview with Louise Hamby.

Source: Photograph by Frank Setzler. Photo Lot 36, Drawer 8. By permission of the Smithsonian Institution, National Anthropological Archives.

34 May 2009. 


\section{Indigenous responses}

How the Aboriginal communities responded to the visitation of scientists is less easy to assess. In its favour, the Expedition arrived with a definite interest in the people and their way of life. This was definitely not the case with many of the Balanda - as white people are known throughout Arnhem Land - whom they typically encountered. The researchers upheld the art, ceremonies and traditional modes of sustenance as valid and important. In this, they differed markedly from the missionaries on Groote and at Oenpelli who were bitterly determined to stamp out 'heathen' customs. Moreover, the Expedition brought with it substantial resources that were distributed in exchange for assistance. Howell Walker's photographs and films document some of the economic exchanges. A National Geographic Society lecture film on the Expedition shows Mountford distributing small blocks of tobacco, the major commodity of trade between Arnhem Landers and Balanda. Still photographs reveal distribution of other goods such as cloth, sewing kits and scissors. The Expedition records show that painters, weavers, carriers and guides were all paid for their services.

This is not to deny that there were detrimental aspects to the Expedition. The medical researchers pricked and prodded their subjects. They took samples of blood, breast milk and excrement for analysis. Frank Setzler, a protégée of the Smithsonian's Aleš Hrdlička (a founding figure in American physical anthropology) collected hair samples, fingerprints and made facial casts. There was much that was intrusive and even more that was perplexing. The taking of stool samples was deeply problematic: associated with sorcery in Aboriginal culture. The fact that the Expedition brokered so many cooperative relationships at its three bases, and on its many side trips, suggests a basic willingness to share culture and participate in the education of the visitors. But in some respects, the loyalty was tested. The most controversial aspect of the Expedition's work - certainly by today's standards - was Setzler's collection of human bones from mortuary caves and other sites. Nearly all ended up at the Smithsonian Institution, ostensibly on loan. In 2008, at the request of the Australian Government, the Smithsonian returned about two thirds of the Aboriginal human remains to their communities of origin. ${ }^{35}$ In 2010 the Smithsonian released the remaining third to a delegation of traditional owners and they have now been returned to Australia.

35 The Expedition also excavated several graves of trepangers from Macassar who had died on the coast of Arnhem Land. These remains are still in the collection of the Smithsonian Institution's National Museum of Natural History. 


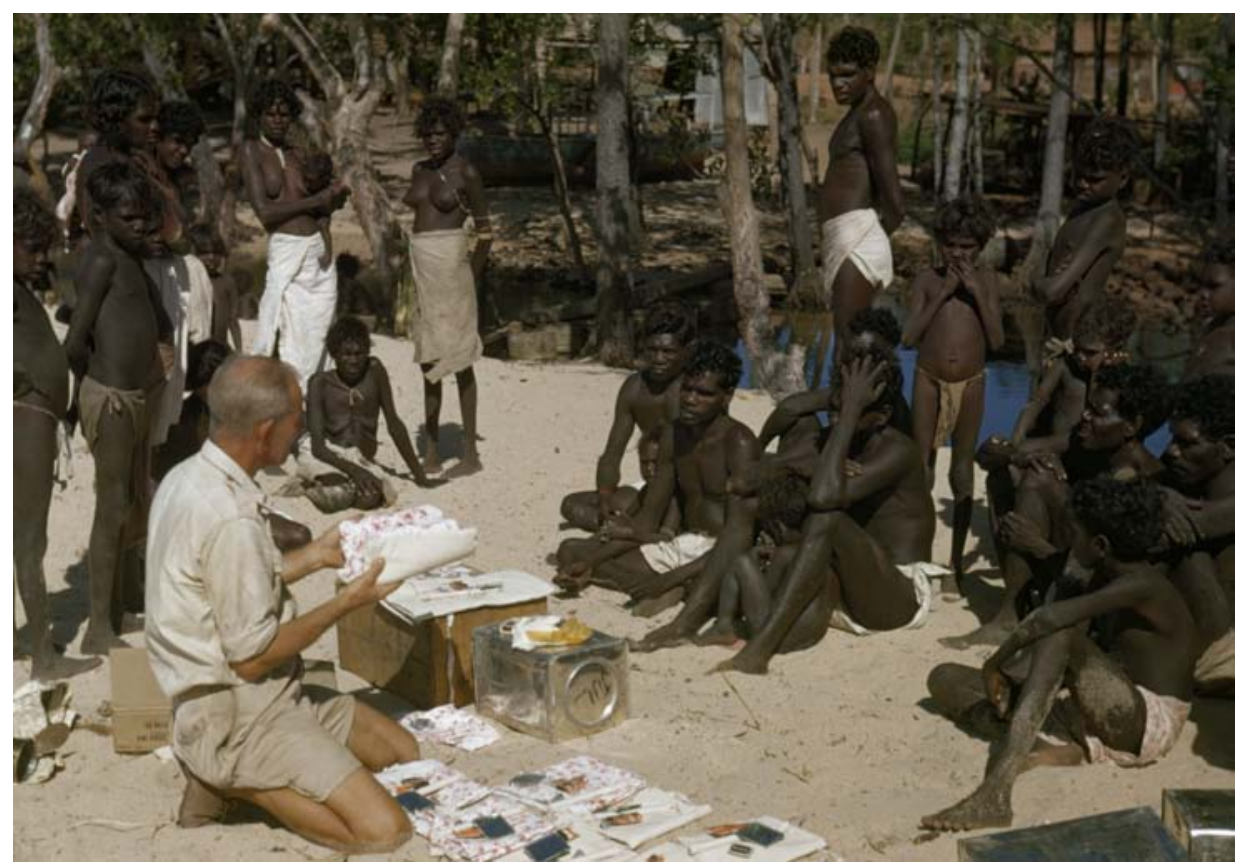

Fig 4. Charles $P$ Mountford distributing payment at Yirrkala during Arnhem Land Expedition in 1948. Margaret Djuwandayngu Yunupingu has identified a number of people in the photograph. Wandjuk Marika is the man seated with hand on his head. Yama Munugritja, wearing a loin cloth, stands behind him. Madjidi Wanambi is the man seated to the right of Wandjuk. To his right is Mathaman Marika.

Source: Photograph by Howell Walker. Slide box 111. By permission of National Geographic Stock.

Unfortunately, many of the people who posed in photographs were not identified. This is also the case with Aborigines of the Sea Coast (1950), Arnhem Land (1950) and Birds and Billabongs (1951), the three Expedition films from Australia, released by the Commonwealth Film Unit. The language barriers were considerable and even the transcriptions of names posed problems. Mountford's documentation of artists' names is patchy, and the identities of weavers, fibre workers and toolmakers are, in many cases, lost forever. However, some people who worked with the Expedition were identified, and a few became prominent in later years. Yolngu man Mawalan Marika, recognised as one of the greatest painters of north-east Arnhem Land, worked with the Expedition and contributed to the collection of paintings. His son Wandjuk Marika (1927-1987) was also a painter, but achieved particular prominence as a Yolngu leader and spokesman. A compelling advocate for Aboriginal art, he sat on government committees and was one of the forces behind the Bark Petition, a powerful and historically significant protest against the establishment of bauxite mining at Gove. ${ }^{36}$ Thanks to the Methodist missionaries at Yirrkala, the young Wandjuk 
was fluent in English by the time the Expedition arrived in mid-1948. As chief translator, he was at the centre of negotiations between Mountford's mob and his own people.

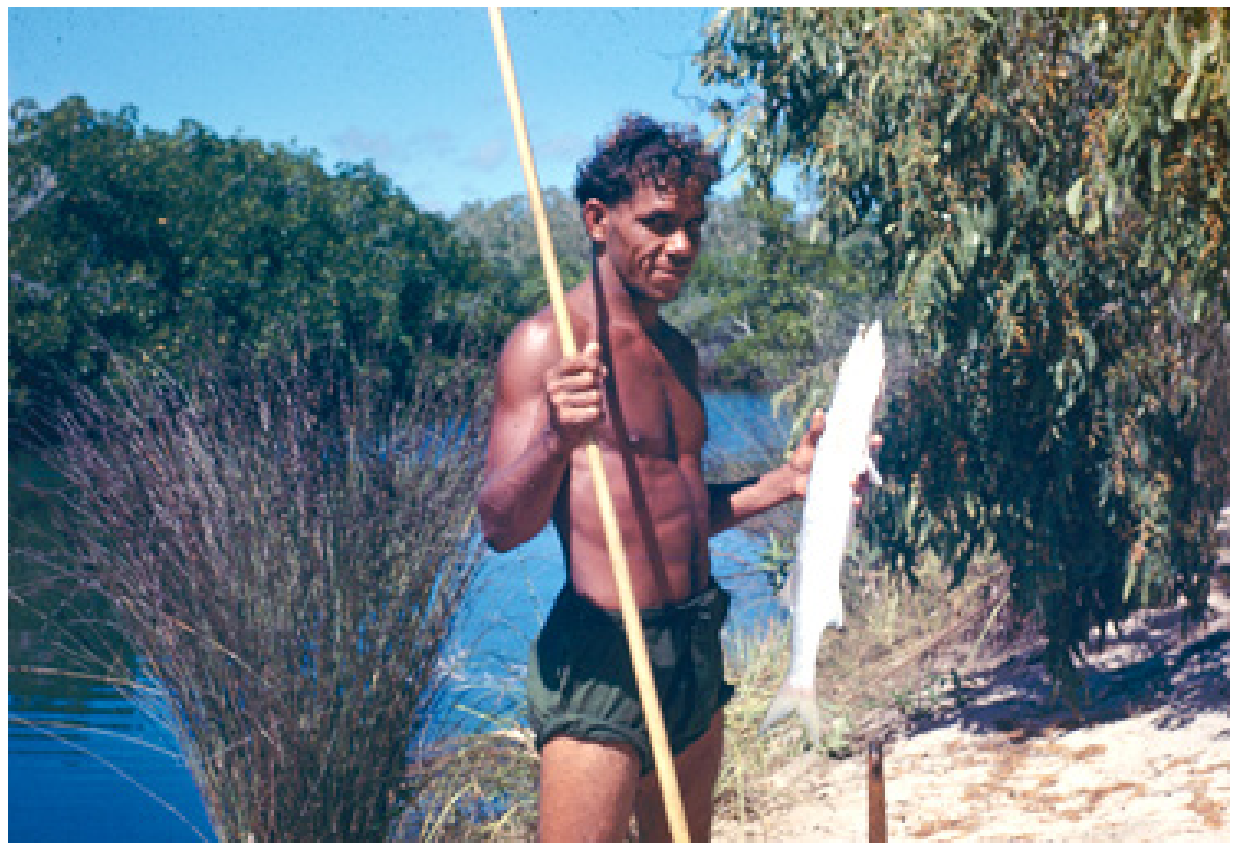

Fig 5. Expedition guide and translator Gerald Blitner on Groote Eylandt, 1948.

Source: Photograph by Robert Rush Miller. nla.pic-vn4515154. Courtesy of the National Library of Australia.

On Groote Eylandt Gerald Blitner (1920-2008) played a similar role. As a child of mixed race heritage, he was taken at the age of four from the mission at Roper River on the mainland to Groote Eylandt. There he was educated at the special 'half-caste' mission, run by the Christian Missionary Society. By 1948, he was working for Fred Gray on the other side of the island, and in this capacity he became translator and guide to the Expedition. About six months before his death, I interviewed him for the National Library of Australia, and he talked at length about his response, and that of the Umbakumba community, to the visiting scientists. This is the most extensive record of the Expedition from an Aboriginal perspective. Blitner believed that Mountford had been too headstrong in his quest for information, particularly that of a secret-sacred nature. But for the most part Blitner was sanguine about the 1948 experience, emphasising how much he learnt about the ways of white people from his involvement. Blitner went on to have a varied career that included crocodile shooting, captaincy of a small boat, and retailing. ${ }^{37}$ In the 1980s, he served as chairman of the Northern Land Council, a central position in Aboriginal politics. The leadership roles played by both Marika and Blitner are indicative of their ability to represent

37 Gerald Blitner in interview with the author, 27-28 September 2007, NLAOHC, Oral TRC 5851. 
Aboriginal culture to a wider populace. Blitner's own testimony suggests that the Expedition, alongside other experiences, helped in the development of this intercultural dexterity. This was part of a broader pattern that helps explain Arnhem Landers' receptivity to the Expedition. Here was an opportunity for them to learn about Balanda, while Balanda learned about them. ${ }^{38}$

Some critics would argue that the Arnhem Land Expedition was essentially concerned with the appropriation of Aboriginal culture by white Australians and Americans. Here is yet another example of the way 'the West' has manipulated 'the Rest' for its own purposes. Catherine Lutz and Jane Collins have said as much about National Geographic in an influential critique of the magazine. ${ }^{39}$ Persuasive as their argument is, it is somewhat complicated by experiences such as mine with Gerry Blitner. So often the postcolonial critique is as oblivious to the perspective of the colonised person as the thing it criticises. When I showed Blitner Mountford's extensive article on the Expedition, published in National Geographic in late 1949, he was dismayed that despite his contribution as guide and interpreter, there was no photograph of him. This was far more concerning than the article's politically incorrect title, 'Exploring Stone Age Arnhem Land' ${ }^{40}$ His disappointment was somewhat assuaged by film footage I showed him, taken by Howell Walker with whom he developed a warm relationship. ${ }^{41}$ With cries of delight, he watched himself as a muscular 28 year old, engrossed in the business of skinning a crocodile.

His response to the film footage is evidence of the sort of ownership Arnhem Landers feel towards the photography, sound recordings and artefacts amassed in 1948. They inevitably see them as their cultural property. On several occasions I have gone to locations visited by the Expedition and experienced the warmth with which movie and audio footage is received by descendant communities. This work of taking things back to their place of origin has provided important opportunities to identify locations and individuals, and to allow people to engage with how their forebears did things 60 years ago. ${ }^{42}$ Invariably, the photographic and audio records are identified as important aspects of the local culture, pleasurable to experience and redolent with possibilities for educating young people about how things were done in earlier days. The people with whom I spoke were hyper-attentive to the way their relatives acted for the camera or recorder. They were highly discerning in their appreciation of the singing and dancing. People in Yirrkala, when explaining the motivations of those who were documented so long ago, interpreted the films and recordings as gifts, left by their forebears for future generations.

These responses to the historic material are suggestive of how the people of Arnhem Land engaged with the technological opportunities offered by the Expedition. Colin Simpson left a detailed account of this, describing the

38 Thomas 2011.

39 Lutz and Collins 1993.

40 Mountford 1949.

41 Walker 1949.

42 Thomas 2007b. 
excitement with which singers listened back to their recordings. He related how an Oenpelli man named Marawana, a brilliant didgeridoo player, monitored his work and re-recorded when he detected a mistake. ${ }^{43}$ If looking for antecedents to such remarkable collaborations as the film Ten Canoes (2006), directed by Rolf de Heer in association with the Yolngu community at Ramingining, the historical importance of this early documentary-making can be discerned. ${ }^{44}$ The 1948 material is the antithesis of 'fly on the wall' filmmaking. Rather, it is the documentation of premeditated performances of aspects of the culture; performances that came about as a consequence of negotiations and exchanges. So it is not surprising that in the larger regional centres of Arnhem Land, people are doing their utmost to claw back documentation of their own kin and make it accessible in digital form. In Yirrkala, the local community has launched the Mulka Project, a digital knowledge centre that makes film, photos and sound recordings from archives around the world immediately accessible to traditional owners. ${ }^{45}$ Expedition material is among the huge array of data that have been added to the Mulka Project's ever-expanding archive.

\section{The continuing legacy}

The enduring relevance of the Expedition to the people of Arnhem Land raises broader questions about its significance and legacy. Colin Simpson judiciously observed that:

[w] hat it accomplished is said to have been scientifically considerable, but is not measurable now, and perhaps never will be. Such findings take years to write and codify and publish and disseminate. When that is completed, the use of them is only at a beginning. ${ }^{46}$

The fact that Aboriginal people are taking ownership of the documentation is an example of how consequences can defy intentions. When the Expedition was conceived, no one argued that the subjects of study might one day be beneficiaries of it. At that time the narrative of racial decline was so compelling that even its greatest skeptics had difficulty thinking beyond it. In his original grant application, Mountford claimed that Aboriginal painting must be studied urgently 'because the art is disappearing rapidly'. Yet as it turned out, the reverse happened. Oenpelli and Yirrkala have thriving art movements. There, and in other parts of Arnhem Land, painting remains a favored occupation. A deeply social activity that occurs within the community (unlike many other types of employment), it affirms the ancient stories and traditions while opening opportunity for new thinking and ideas. In these localities where poverty is endemic, it constitutes an important stream of income.

43 Simpson, 1951: 67.

44 Thomas 2010.

45 See Anon, 'The Mulka Project', accessed 13 April 2009: <http://www.yirrkala.com/mulka/ index.html>.

46 Simpson 1951: 40. 
When considering the fairly healthy state of Arnhem Land's art production, it is only fair to acknowledge that Mountford's collection of paintings, at a time when they were barely recognised as art, played a substantial role in inculcating the interest and connoisseurship on which the contemporary Aboriginal art market depends. His extensive publications, popular and scholarly, and the placement of Expedition paintings in flagship institutions, had significant influence on the international profile of Aboriginal painting. ${ }^{47}$ The dispersal of the Commonwealth's share of the 1948 paintings was particularly important. Since there was at that time no national museum of art or natural history, it was decided in 1956 to distribute the works among Australia's six state galleries. This is seen as a watershed moment, since it marked the admissibility of Aboriginal paintings to the major fine art institutions. Previously they had been treated as ethnological 'specimens' in museums. ${ }^{48}$ With the benefit of a long-term perspective, the Arnhem Land Expedition can be seen as a venture that opened all sorts of conduits for the survival and recognition of Aboriginal culture in the modern era. This occurred in spite of the fact that Mountford, its instigator, was for the most part an adherent to an old school notion of 'salvage' anthropology, ever determined to gather the surviving fragments of what was, to him, a vanishing world.

It might be asked why this grand event, reported avidly in its day, faded from public memory. Could it be that the rather nineteenth-century concept of a scientific expedition began to look dated? Certainly, the anthropological establishment, which was snubbed and sidelined by Mountford's appointment as leader, did all in its power to diminish it. Ronald Berndt, Elkin's loyal acolyte, was nothing less than vitriolic in his review of Art, Myth and Symbolism. ${ }^{49}$ Elkin himself said of the Expedition, 'I see Mountford is busily discovering things that have been known for years. ${ }^{50}$ Yet it can also be argued that the Expedition ceased to be noticed because much of what it pioneered became commonplace. Scores of filmmakers and photographers have followed in its footsteps. In 1949 Elkin himself teamed up with the poet and ABC broadcaster John Thompson to document songs and ceremonies at Mainoru, just south of the Arnhem Land border - an ABC collaboration uncannily reminiscent of Mountford's work with Simpson. ${ }^{51}$ Writing of the broader disciplinary intersections, Anne Clarke positions the Arnhem Land Expedition as 'a precursor of more recent, multidisciplinary research projects such as the Kakadu Archaeological Project of the early 1980s.' 52 Mountford's technique of eliciting narratives on rock art from local guide-cum-artists is now standard practice in the many rock art studies occurring in Arnhem Land and elsewhere. His career as an autodidact in rock art scholarship provided raw data - and inspiration - to later workers in this mould such as George Chaloupka. ${ }^{53}$ 
The Expedition pursued a catholic range of inquiries, but the fact that it roved so widely through various locations resulted in a lack of in-depth ethnography at any one place. In particular, the meagerness of its contribution to kinship study rendered it uninteresting to anthropologists of the 1950s and 1960s. This has now turned around with the emergence of visual anthropology and renewed interest in museology. Collections of museum objects are fuelling new types of historical investigation, while ethnographic film and photography are now acknowledged as important primary records, rather than interesting ephemera. Yet there were aspects of the 1948 research that profoundly affected anthropological theory, none more so than McArthur's time and motion studies of food-gathering activities at Fish Creek and Hemple Bay. This research was published in a paper titled 'The Food Quest and the Time Factor in Aboriginal Economic Life' that she co-authored with McCarthy. ${ }^{54}$ It rapidly became prescribed reading for first year anthropology students in many parts of the world. The findings were arresting because they challenged the long-held Western assumption that hunter-gatherers invariably lead lives of unmerciful toil, a ceaseless 'struggle for existence'. In contradiction to the received wisdom, the 'Food Quest' paper argued that the labour of meeting daily food needs was dispensed with fairly quickly, so that clans in Arnhem Land had ample time to spend with their children, devote to cultural activities, or otherwise pass as they pleased.

Among those intrigued and influenced by the findings was the Chicago anthropologist, Marshall Sahlins, now regarded as one of the most influential voices in the discipline. So 'startling' did he find the Expedition data that he insisted they 'must provoke some review of the Australian reportage going back for over a century, and perhaps revision of an even longer period of anthropological thought. ${ }^{55}$ The Arnhem Land work was a catalyst for Sahlins' idea of the 'original affluent society', a theory that shifted anthropological debate since it argued against notions of primitivism and instead proposed that the hunter-gatherer lifestyle was a sophisticated response to its environment, designed to satisfy the needs and welfare of the entire community.

As for the United States-Australia relationship, can we say that it was strengthened or even influenced by the 'friendly mission' in Arnhem Land? That would be a bold claim, given the scale of the global realignments occurring at that formative moment. Yet we can say safely that the Expedition was a microcosm of sorts. In the coolness of that early Cold War moment, it set the tone for what was sayable and unsayable in the relationship between Canberra and Washington, as the redoubtable Consul Seibert revealed in the conclusion to his classified report on the troubles of the Arnhem Land Expedition.

I received long-distance-telephone inquiries from the press from as far away as Sydney on the subject of the rumoured rift (to which I replied in tenor directly contrary to the truth), and doubtless the others concerned were likewise quizzed, but, so far as I know, not a hint of the true

54 McCarthy and McArthur 1960.

55 Sahlins 1972: 14. 
situation appeared in print. The expedition was subjected to numerous social and official entertainments in Adelaide, which were marked by an atmosphere of unadulterated sweetness and light. Mr Setzler and the other Americans, like the Australians, made themselves extremely popular during their two short stays in South Australia, and I had every reason to be proud of them. ${ }^{56}$

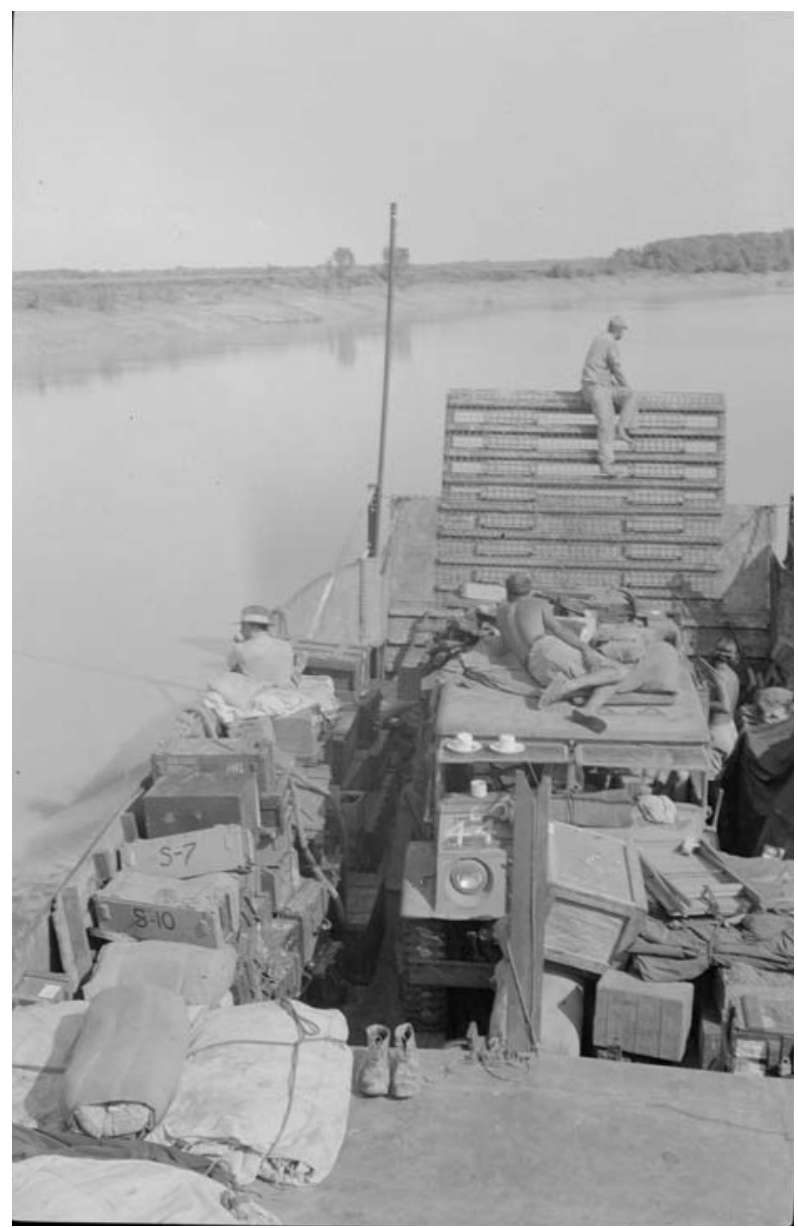

Fig 6. Barge transporting equipment and collections down the East Alligator River at the end of the Expedition in November 1948.

Source: Photograph by Frank Setzler. Photo Lot 36, Drawer 8. By permission of the Smithsonian Institution, National Anthropological Archives.

56 Seibert to Secretary of State, 24 December 1948, Foreign Service Posts of the Department of State, Australia, Canberra Embassy, Confidential File 1948 RG 84, Box 16, NARA. 


\section{Acknowledgments}

Thanks to Margaret Djuwandayngu Yunupingu, Joe Neparrnga Gumbula and Louise Hamby for identification of people photographed in 1948. I am equally indebted to the Smithsonian Institution for granting me a Smithsonian Fellowship in 2008 which made possible the primary research in the United States.

\section{References}

\section{Primary sources}

American/Australian Scientific Expedition to Arnhem Land 1948 Records, Mountford-Sheard Collection, State Library of South Australia, Adelaide.

Arnhem Land Expedition file 178294, Accession Files (Record Unit 305), Smithsonian Institution Archives, Washington DC.

Frank Maryl Setzler Papers 1927-1960, National Anthropological Archives, Smithsonian Institution, Suitland, Maryland.

Institute of Anatomy Records, National Archives of Australia, Canberra.

Papers of Frederick David McCarthy, Australian Institute of Aboriginal and Torres Strait Islander Studies.

Oral History Collection, National Library of Australia, Canberra.

Records of the Foreign Service Posts of the Department of State, United States National Archives and Records Administration, College Park, Maryland.

Robinson, Lee (director) 1947, Namatjira the Painter, Commonwealth Department of Information.

Walker, Howell (cine-photographer) 1949, Aboriginal Australia (lecture film), National Geographic Society Film Archives, Washington DC.

\section{Secondary sources}

Anon, 'The Mulka Project', accessed 13 April 2009: <http:/ / www.yirrkala.com/ mulka/index.html>

Beazley, Kim 2011, 'Nation building or Cold War: political settings for the Arnhem Land Expedition', in Exploring the Legacy of the 1948 American-Australian Scientific Expedition to Arnhem Land, Margo Neale and Martin Thomas (eds), ANU E Press, Canberra. 
Berman, Edward H 1983, The Ideology of Philanthropy: the Influence of the Carnegie, Ford, and Rockefeller Foundations on American Foreign Policy, State University of New York Press, Albany.

Berndt, Ronald M 1958, 'The Mountford volume on Arnhem Land art, myth and symbolism: a critical review', Mankind 5(6): 249-261.

Chaloupka, George 1999, Journey in Time: The 50,000-year Story of the Australian Aboriginal Rock Art of Arnhem Land, Reed New Holland, Sydney.

Clarke, Anne 1998, 'Engendered fields: the language of the 1948 AmericanAustralian Expedition to Arnhem Land', in Redefining Archaeology: Feminist Perspectives, Mary Casey, Denise Donlon, Jeannette Hope and Sharon Wellfare (eds), ANH Publications, Research School of Pacific and Asian Studies, Canberra.

Cole, Keith 1984, Fred Gray of Umbakumba: the Story of Frederick Harold Gray, the Founder of the Umbakumba Aboriginal Settlement on Groote Eylandt, Keith Cole Publications, Bendigo, Victoria.

Elkin, AP 1972, Two Rituals in South and Central Arnhem Land, Oceania Monographs, Sydney.

Gray, Geoffrey 2007, A Cautious Silence: the Politics of Australian Anthropology, Aboriginal Studies Press, Canberra.

Jones, Philip 1988, 'Perceptions of Aboriginal art: a history', in Dreamings: the Art of Aboriginal Australia, Peter Sutton (ed), Viking, Ringwood, Victoria.

- 2000, 'Mountford, Charles Pearcy (1890 - 1976)', Australian Dictionary of Biography, vol 15, Melbourne University Press, Melbourne: 431-433.

Lamshed, Max 1972, 'Monty': the biography of C P Mountford, Rigby, Adelaide.

Lutz, Catherine A and Jane L Collins 1993, Reading National Geographic, University of Chicago Press, Chicago.

MacLeod, Roy M 2000, 'Introduction', in Science and the Pacific War: Science and survival in the Pacific, 1939-1945, Roy M MacLeod (ed), Kluwer, Dordrecht, Boston: 1-12.

Marika, Wandjuk 1995, Wandjuk Marika: Life Story as Told to Jennifer Isaacs, University of Queensland Press, St Lucia, Queensland.

May, Sally K 2010, Collecting Cultures: Myth, Politics, and Collaboration in the 1948 Arnhem Land Expedition, AltaMira Press, Lanham, Maryland. 
McCarthy, Frederick D and Margaret McArthur 1960, 'The food quest and the time factor in Aboriginal economic life', in Anthropology and Nutrition, vol 2 of Records of the American-Australian Scientific Expedition to Arnhem Land, Charles P Mountford (ed), Melbourne University Press, Melbourne.

Mountford, Charles P 1939, 'Aboriginal decorative art from Arnhem Land, Northern Territory of Australia', Transactions of the Royal Society of South Australia 63(2): 365-371.

- 1944, The Art of Albert Namatjira, Bread and Cheese Club, Melbourne.

1946, 'Earth's most primitive people: a journey with the Aborigines of Central Australia', National Geographic Magazine 89(6): 89-112.

- 1946, 'Exploring Stone Age Arnhem Land', National Geographic Magazine 96(6): 745-782.

- 1956, Art, Myth and Symbolism, vol 1 of Records of the American-Australian Scientific Expedition to Arnhem Land, Charles P Mountford (ed), Melbourne University Press, Melbourne.

Neale, Margo 1998, 'Charles Mountford and the "Bastard Barks": a gift from the American-Australian Scientific Expedition to Arnhem Land', in Brought to Light: Australian Art 1850-1965, Lynne Seear and Julie Ewington (eds), Queensland Art Gallery, Brisbane.

Rosenberg, Emily S 1982, Spreading the American Dream: American Economic and Cultural Expansion, 1890-1945, Hill and Wang, New York.

Sahlins, Marshall 1972, Stone Age Economics, Aldine Atherton, Chicago.

Simpson, Colin 1951, Adam in Ochre: Inside Aboriginal Australia, Angus \& Robertson, Sydney.

Thomas, Martin 2007a, 'The rush to record: transmitting the sound of Aboriginal culture', Journal of Australian Studies 90: 105-121.

- 2007b, 'Taking them back: archival media in Arnhem Land today', Cultural Studies Review 13(2): 20-37.

- 2010, 'The crackle of the wire: media, digitization and the voicing of Aboriginal languages', in Voice: Vocal Aesthetics in Digital Arts and Media, Norrie Neumark, Ross Gibson and Theo Van Leeuwen (eds), MIT Press, Cambridge, MA: 71-90. 
- 2011, 'Unpacking the testimony of Gerald Blitner: cross-cultural brokerage and the Arnhem Land Expedition', in Exploring the legacy of the 1948 American-Australian Scientific Expedition to Arnhem Land, Margo Neale and Martin Thomas (eds), ANU E Press, Canberra.

Vosburgh, Frederick G 1966, 'To Gilbert Grosvenor: a monthly monument 25 miles high', National Geographic Magazine 130(4): 445-487.

White, Michael A 1997, 'Carnegie philanthropy in Australia in the nineteen thirties: a reassessment', History of Education Review 26(1): 1-24.

Wise, Tigger 1985, The Self Made Anthropologist: a Life of A P Elkin, George Allen \& Unwin, Sydney. 